RASĀYAN J. Chem.

Vol. 13 | No. 3 |1506-1512| July - September | 2020 ISSN: 0974-1496 | e-ISSN: 0976-0083 | CODEN: RJCABP

RJC http://www.rasayanjournal.com http://www.rasayanjournal.co.in

\title{
DESIGN, SYNTHESIS, CHARACTERIZATION AND BIOLOGICAL EVALUATION OF ARYL PYRAZOLE- INDANONE HYBRIDS
}

\author{
U. B. Chougale',, H. V. Chavan ${ }^{3}$, S. M. Deshmukh ${ }^{4}$, P. R. Kharade ${ }^{2}$ \\ and S. R. Dhongade ${ }^{1, *}$ \\ ${ }^{1}$ Research Laboratory in Heterocyclic Chemistry, Devchand College, Arjunnagar, \\ Tal. Kagal, Dist. Kolhapur-591269 (MH), India. \\ ${ }^{2}$ Karmaveer Hire Arts, Science, Commerce and Education College Gargoti. Tal. Bhudargad, \\ Dist. Kolhapur-416 209 (MH), India. \\ ${ }^{3}$ Department of Chemistry, A. S. P. College, Devrukh, Dist: Ratnagiri (Autonomous), \\ Maharashtra, India-415 804 (MH), India. \\ ${ }^{4}$ Department of Chemistry, V.N.B.N. Mahavidyalaya Shirala, Dist. Sangli-415408 (MH), India. \\ *E-mail: savitadesai2010@gmail.com
}

\begin{abstract}
A series of aryl pyrazole-indanone hybrids were synthesized by the Knoevenagel condensation of 5-chloro-3methyl-1-phenyl-1H-pyrazole-4-carbaldehyde $\mathbf{4}$ with various 1-indanones 5 at room temperature. The structural investigations were carried out with IR, ${ }^{1} \mathrm{H}$ NMR and mass spectral data. All the newly synthesized compounds were assessed for their anticancer and antimicrobial properties. Among the compounds screened $\mathbf{6 d}$, $6 \mathbf{6}$ and $\mathbf{6 f}$ displayed moderate anticancer potential against $\mathrm{MCF}-7\left(\mathrm{IC}_{50} 42.6-53.9 \mu \mathrm{M}\right)$. On the other hand compounds $6 \mathbf{6}, 6 \mathbf{6 b}, \mathbf{6 c}, \mathbf{6 d}$ and $\mathbf{6 g}$ unveiled potent activity against $\mathrm{S}$. aureus and compound $\mathbf{6 c}$ and $\mathbf{6 b}$ displayed moderate activity against E. coli. Keywords: Aryl Pyrazole, Indanone, Anticancer, Antimicrobial.
\end{abstract}

(C) RASĀYAN. All rights reserved

\section{INTRODUCTION}

Pyrazoles and its derivatives are a class of well-known nitrogen-containing heterocycles with diverse biological properties. Pyrazole analogs have also found to use as versatile building blocks in organic synthesis for designing pharmaceuticals and agrochemicals. They have been known to exhibit antimicrobial, ${ }^{1}$ anticancer, ${ }^{2}$ anti-inflammatory, ${ }^{3}$ and selective enzyme inhibitory activities. ${ }^{4}$ Moreover, a series of pyrazole derivatives are also used as insecticides, ${ }^{5}$ fungicides, ${ }^{6}$ and herbicides. ${ }^{7}$ The pyrazole ring is present as the core in a variety of leading drugs such as Celebrex, Sildenafil (Viagra), ionazolac, Rimonabant and Difenamizole, etc. Furthermore, pyrazole compounds, such as pyrazophos, penthiopyrad and pyraclostrobin, have been found to have potential antifungal properties for the control of some plant diseases (Fig.-1).<smiles>CCOC(=O)c1ccc2cc(OP(=S)(OCC)OCC)nn2c1</smiles>

Pyrazophos<smiles>CC(C)CC(C)c1sccc1NC(=O)c1cn(C)nc1C(F)(F)F</smiles>

Penthiopyrad<smiles>COC(C(C)=O)c1ccccc1COc1cnn(-c2ccc(Cl)cc2)c1</smiles>

Pyraclostrobin

Fig.-1: Pyrazole Nucleus Containing Marketed Drugs

Rasayan J. Chem., 13(3), 1506-1512(2020)

http://dx.doi.org/10.31788/RJC.2020.1335716 
RASĀYAN J. Chem.

Vol. 13 | No. 3 |1506-1512| July - September | 2020

1-Indanone and its structural analogs have also been played an important role in the field of medicine and agriculture. The presence of active methylene hydrogens adjacent to the carbonyl group of indanone makes it important in condensation reactions or some organic transformations. ${ }^{8}$ In recent years indanone derivatives with anticancer, ${ }^{9}$ antibacterial, ${ }^{10}$ antiviral, ${ }^{11}$ anticonvulsant, ${ }^{12}$ antimicrobial, ${ }^{13}$ antidiabetic, ${ }^{14}$ antimalarial, ${ }^{15}$ anti-inflammatory ${ }^{16}$ activities have been reported. Indanone derivatives also found useful in the treatment of Alzheimer's diseases, ${ }^{17}$ as well as insecticidal in the agrochemical field. ${ }^{18}$ The structures of some biologically active 1-indanone derivatives ${ }^{14,15,19}$ are depicted in Fig.-2.<smiles>Cc1cccc2c1CC/C2=N\NC(N)=S</smiles>

Antibacterial<smiles>COc1cc2c(cc1OC)C(=O)C(CC1CCN(Cc3ccccc3)CC1)C2</smiles>

Cardiovascular<smiles>Cc1cc2c(c(C)c1CCO)C(=O)C(C)C2O</smiles>

Antiviral<smiles>COC1CC(=O)c2c(C=O)cc(C)cc21</smiles>

Anticancer

Fig.-2: Biologically Active 1-Indanones and their Derivatives

The combination of active scaffolds may offer a synergistic effect to improve therapeutic potential. Based on these observations and in continuation of our interest ${ }^{20}$ in the synthesis of novel bioactive molecules with potential anticancer properties we herein synthesized hybrid scaffolds containing aryl pyrazole framework combined with various substituted 1-indanones and evaluated for their anticancer and antimicrobial properties.

\section{EXPERIMENTAL}

\section{Material and Methods}

IR spectra were recorded on FT-IR Nicolet iS 10 spectrophotometer and ${ }^{1} \mathrm{H}$ NMR spectra were recorded on a Bruker $400 \mathrm{MHz}$ spectrometer in $\mathrm{CDCl}_{3}$ using TMS as an internal standard and chemical shifts are reported in $\delta$ units and the coupling constants $(J)$ are reported in Hertz. Mass spectra were obtained with a Shimadzu LCMS-2010EV. TLC was performed on an aluminum-backed silica plate with visualization by UV-light.

General Procedure for the Preparation of (2E)-2-[(5-Chloro-3-methyl-1-phenyl-1H-pyrazol-4-yl)methylidene]-2,3-dihydro-1 $H$-inden-1-one (6a-f)

In a round bottom flask, a mixture of 5-chloro-3-methyl-1-phenyl- $1 \mathrm{H}$-pyrazole-4-carboxaldehyde 4 $(0.220 \mathrm{~g}, 1 \mathrm{mmol})$ and 1 -indanone $5(0.132 \mathrm{~g}, 1 \mathrm{mmol})$ was dissolved in ethanol $(15 \mathrm{~mL})$ under stirring. To this solution was added sodium hydroxide $(0.12 \mathrm{~g}, 3 \mathrm{mmol})$ dissolved in a minimum quantity of water and stirring continued for $1 \mathrm{~h}$. The completion of the reaction was monitored by TLC. After completion of the reaction, the solid product obtained was filtered off and washed with little cold ethanol. The crude product was dried and recrystallized from ethanol to obtain the desired product $\mathbf{6}$ in pure form.

Preparation of 3-Methyl-1-phenyl-2-pyrazolin-5-one (3)

A mixture of ethyl acetoacetate $(5.2 \mathrm{~g}, 5.2 \mathrm{~mL}, 0.04 \mathrm{~mol})$ and phenylhydrazine $(4.3 \mathrm{~g}, 3.94 \mathrm{~mL}, 0.04 \mathrm{~mol})$ was taken in a $100 \mathrm{~mL}$ round bottom flask and heated at $120{ }^{\circ} \mathrm{C}$ with constant stirring under the solvent- 
free condition for $4 \mathrm{~h}$ on an oil bath. The completion of the reaction was monitored by TLC. After completion of the reaction, the reaction mixture was cooled and diethyl ether $(20 \mathrm{~mL})$ was added to it. The obtained solid was filtered, washed with diethyl ether and recrystallized from ethanol to obtain the pure product 3-methyl-1-phenyl-2-pyrazolin-5-one (3) in excellent yield.

\section{Preparation of 5-Chloro-3-methyl-1-phenyl-1H-pyrazole-4-carbaldehyde (4)}

A mixture of 3-methyl-1-phenyl-2-pyrazolin-5-one 3 (2.205 g, $0.018 \mathrm{~mol})$ and dimethylformamide (DMF) $(10 \mathrm{~mL}, 0.13 \mathrm{~mol})$ was taken in a three-neck round-bottomed flask equipped with reflux condenser under an inert atmosphere. The reaction mixture was cooled at $0{ }^{\circ} \mathrm{C}$ and treated with $\mathrm{POCl}_{3}$ ( $4.6 \mathrm{~g}, 2.8 \mathrm{~mL}, 0.03$ mole), maintaining the temperature between $10-15{ }^{\circ} \mathrm{C}$. After complete addition, the reaction mixture was heated on a water bath for about $3 \mathrm{~h}$, cooled, and poured into ice water with vigorous stirring to obtain the desired compound $\mathbf{4}$ in good yield. The product obtained was recrystallized from ethanol as yellow needles.

Spectral data of representative compounds:

(E)-2-((5-Chloro-3-methyl-1-phenyl-1H-pyrazol-4-yl)methylene)-2,3-dihydro-1H-inden-1-one (6a) ${ }^{1} \mathrm{H}$ NMR $\left(\mathrm{CDCl}_{3} 400 \mathrm{MHz}\right): \delta 2.44$ (s, 3H, $\left.-\mathrm{CH}_{3}\right), 3.94$ (s, $\left.2 \mathrm{H},-\mathrm{CH}_{2}-\right), 7.42-7.47$ (m, 2H, -ArH indanone), 7.50-7.91 (m, 7H, $6 x-A r H$, =CH), $7.92(\mathrm{~d}, \mathrm{~J}=7.6 \mathrm{~Hz}, 1 \mathrm{H},-A r H)$; LCMS (ESI): $335.45(\mathrm{M}+1)$.

\section{(E)-2-((5-Chloro-3-methyl-1-phenyl-1H-pyrazol-4-yl)methylene)-6-methoxy-2,3-dihydro-1H-inden-} 1-one (6b)

${ }^{1} \mathrm{H}$ NMR $\left(\mathrm{CDCl}_{3} 400 \mathrm{MHz}\right): \delta 2.41\left(\mathrm{~s}, 3 \mathrm{H}, \mathrm{Pyr}-\mathrm{CH}_{3}\right), 3.86\left(\mathrm{~s}, 2 \mathrm{H},-\mathrm{CH}_{2^{-}}\right), 3.88\left(\mathrm{~s}, 3 \mathrm{H},-\mathrm{OCH}_{3}\right), 7.22(\mathrm{dd}$, $\mathrm{J}=2.8 \mathrm{~Hz}, 8.4 \mathrm{~Hz}, 1 \mathrm{H},-$ ArH indanone $), 7.37(\mathrm{~d}, \mathrm{~J}=2.4 \mathrm{~Hz}, 1 \mathrm{H}$, ArH indanone $), 7.42(\mathrm{~d}, \mathrm{~J}=8.8 \mathrm{~Hz}, 1 \mathrm{H}$, -ArH indanone), $7.46(\mathrm{dd}, \mathrm{J}=1.6 \mathrm{~Hz}, 7.2 \mathrm{~Hz}, 1 \mathrm{H},-\mathrm{ArH}),, 7.50-7.54(\mathrm{~m}, 3 \mathrm{H}, 2 x-\mathrm{ArH}$, $=C H), 7.57-7.59($ $\mathrm{m}, 2 \mathrm{H},-\mathrm{ArH})$; LCMS (ESI): $365.30(\mathrm{M}+1)$.

(E)-2-((5-Chloro-3-methyl-1-phenyl-1H-pyrazol-4-yl)methylene)-5,6-dimethoxy-2,3-dihydro-1Hinden-1-one (6c)

${ }^{1} \mathrm{H}$ NMR $\left(\mathrm{CDCl}_{3} 400 \mathrm{MHz}\right): \delta 2.42$ (s, 3H, $\left.\mathrm{Pyr}-\mathrm{CH}_{3}\right), 3.84$ (s, 2H, $\left.-\mathrm{CH}_{2}-\right), 3.95$ (s, 3H, $\left.-\mathrm{OCH}_{3}\right), 3.99$ (s, $\left.3 \mathrm{H},-\mathrm{OCH}_{3}\right), 6.95(\mathrm{~s}, 1 \mathrm{H},-\mathrm{ArH}$ indanone $), 7.34(\mathrm{~s}, 1 \mathrm{H},-\mathrm{ArH}$ indanone $), 7.44(\mathrm{~m}, 2 \mathrm{H},-\mathrm{ArH}), 7.49-7.52$ $(\mathrm{m}, 2 \mathrm{H},-A r H), 7.56-7.58(\mathrm{~m}, 2 \mathrm{H},-A r H$, $=C H)$; LCMS (ESI): $395.10(\mathrm{M}+1)$.

\section{(Z)-3-((5-Chloro-3-methyl-1-phenyl-1H-pyrazol-4-yl)methylene)indolin-2-one (6f)}

${ }^{1} \mathrm{H}$ NMR $\left(\mathrm{CDCl}_{3} 400 \mathrm{MHz}\right): \delta 2.32\left(\mathrm{~s}, 3 \mathrm{H},-\mathrm{CH}_{3} \mathrm{Pyr}\right), 6.91(\mathrm{~d}, \mathrm{~J}=8 \mathrm{~Hz}, 1 \mathrm{H},-$ ArH indanone $), 6.98(\mathrm{~d}, \mathrm{~J}=$ $8 \mathrm{~Hz}, 1 \mathrm{H},-$ ArH indanone $), 7.20(\mathrm{~d}, \mathrm{~J}=7.6 \mathrm{~Hz}, 1 \mathrm{H},-$ ArH indanone $), 7.24(\mathrm{~d}, \mathrm{~J}=7.6 \mathrm{~Hz}, 1 \mathrm{H},-\mathrm{ArH}$ indanone), $7.64(\mathrm{dd}, \mathrm{J}=1.2 \mathrm{~Hz}, \mathrm{~J}=8 \mathrm{~Hz}, 2 \mathrm{H},-A r H), 7.46(\mathrm{~d}, \mathrm{~J}=7.2 \mathrm{~Hz}, 1 \mathrm{H},-A r H), 7.50-7.56(\mathrm{~m}, 3 \mathrm{H}, 2 x$ $-\mathrm{ArH}, \mathrm{l}=\mathrm{CH}$ ), 8.23 (bs, 1H, -NH-); LCMS (ESI): $336.05(\mathrm{M}+1)$.

\section{MTT Assay For Anticancer Screening}

The cells were seeded at a density of approximately $5 \times 10^{3}$ cells/well in a 96-well flat-bottom microplate and maintained at $37{ }^{\circ} \mathrm{C}$ in $95 \%$ humidity and $5 \% \mathrm{CO}_{2}$ overnight. Different concentration $(500,400,300$, $200,100,50 \mu \mathrm{g} / \mathrm{ml}$ ) of samples was treated. The cells were incubated for another 48 hours. The cells in well were washed twice with phosphate buffer solution, and $20 \mu \mathrm{L}$ of the MTT staining solution $(5 \mathrm{mg} / \mathrm{ml}$ in phosphate buffer solution) was added to each well and plate was incubated at $37^{\circ} \mathrm{C}$. After $4 \mathrm{~h}, 100 \mu \mathrm{L}$ of dimethyl sulfoxide (DMSO) was added to each well to dissolve the formazan crystals, and absorbance was recorded with a $570 \mathrm{~nm}$ using a microplate reader $(1,2)$.

Surviving cells $(\%)=$ Mean OD of test compound $/$ Mean OD of Negative control $\times 100$

Using graph Pad Prism Version 5.1, we calculated the $\mathrm{IC}_{50}$ values of compounds.

Note: DMSO Concentration is less $1.5 \%$ in experiments. Concentrations are in duplicates 
RASĀYAN J. Chem.

Vol. 13 | No. 3 |1506-1512| July - September | 2020

\section{Protocol for Antimicrobial Evaluation: MIC Test (Aerobic)}

The 9 dilutions of each drug have to be done with BHI for MIC. In the initial tube, 20 microliters of the drug were added into the 380 microliters of BHI broth. For dilutions, 200 microliters of BHI broth were added into the next 9 tubes separately. Then from the initial tube, 200 microliters were transferred to the first tube containing 200 microliters of BHI broth. This was considered as 10-1 dilution. From 10-1 diluted tube, 200 microliters were transferred to the second tube to make 10-2 dilution. The serial dilution was repeated up to 10-9 dilution for each drug. From the maintained stock cultures of required organisms, 5 microliters were taken and added into $2 \mathrm{ml}$ of BHI (brain heart infusion) broth. In each serially, diluted tube 200 microliter of above culture suspension was added. The tubes were incubated for 24 hours and observed for turbidity. ${ }^{21}$

\section{Chemistry}

\section{RESULTS AND DISCUSSION}

The synthesis of target molecules (6a-g) was achieved by the Knoevenagel condensation of 5-chloro-3methyl-1-phenyl-1H-pyrazole-4-carbaldehyde (4) with 1 -indanone (5) in at room temperature in the presence of sodium hydroxide in ethanol in good to excellent yield (Scheme-1). The precursor 5-chloro-3methyl-1-phenyl-1H-pyrazole-4-carbaldehyde (4) was synthesized by Vilsmeyer-Hack formylation of 3methyl-1-phenyl-2-pyrazolin-5-one (3). The synthesis of starting compound 3-methyl-1-phenyl-2pyrazolin-5-one (3) was accomplished under solvent-free condition by the condensation of ethyl acetoacetate (1) and phenyl hydrazine $(2)$ at $120{ }^{\circ} \mathrm{C}($ Scheme-2). The structural investigation of the synthesized compounds was carried out using IR, ${ }^{1} \mathrm{H}$ NMR and mass spectral data. The structures of synthesized compounds are presented in Table-1.<smiles>Cc1nn(-c2ccccc2)c(Cl)c1C=O</smiles>

4<smiles>[R]c1cc2c(cc1[R])C(=O)CC2</smiles>

5

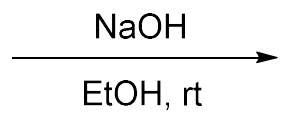<smiles>[R]c1cc2c(cc1[R])C(=O)/C(=C/c1c(C)nn(-c3ccccc3)c1Cl)C2</smiles>

$6 a-g$

Scheme-1: Synthesis of Aryl Pyrazole-indanone Hybrids

Table-1: Structures of the Aryl Pyrazole-1-indanone Hybrids

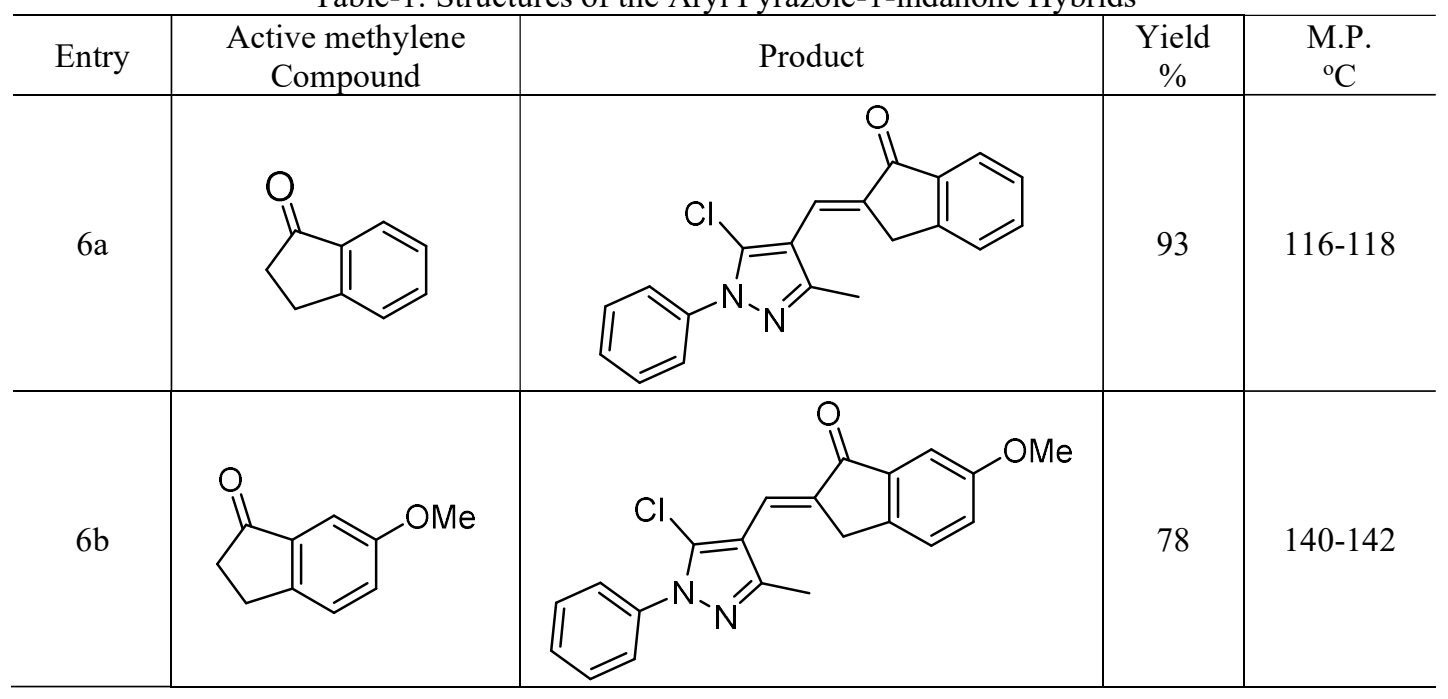


RASĀYAN J. Chem.

Vol. 13 | No. 3 |1506-1512| July - September | 2020

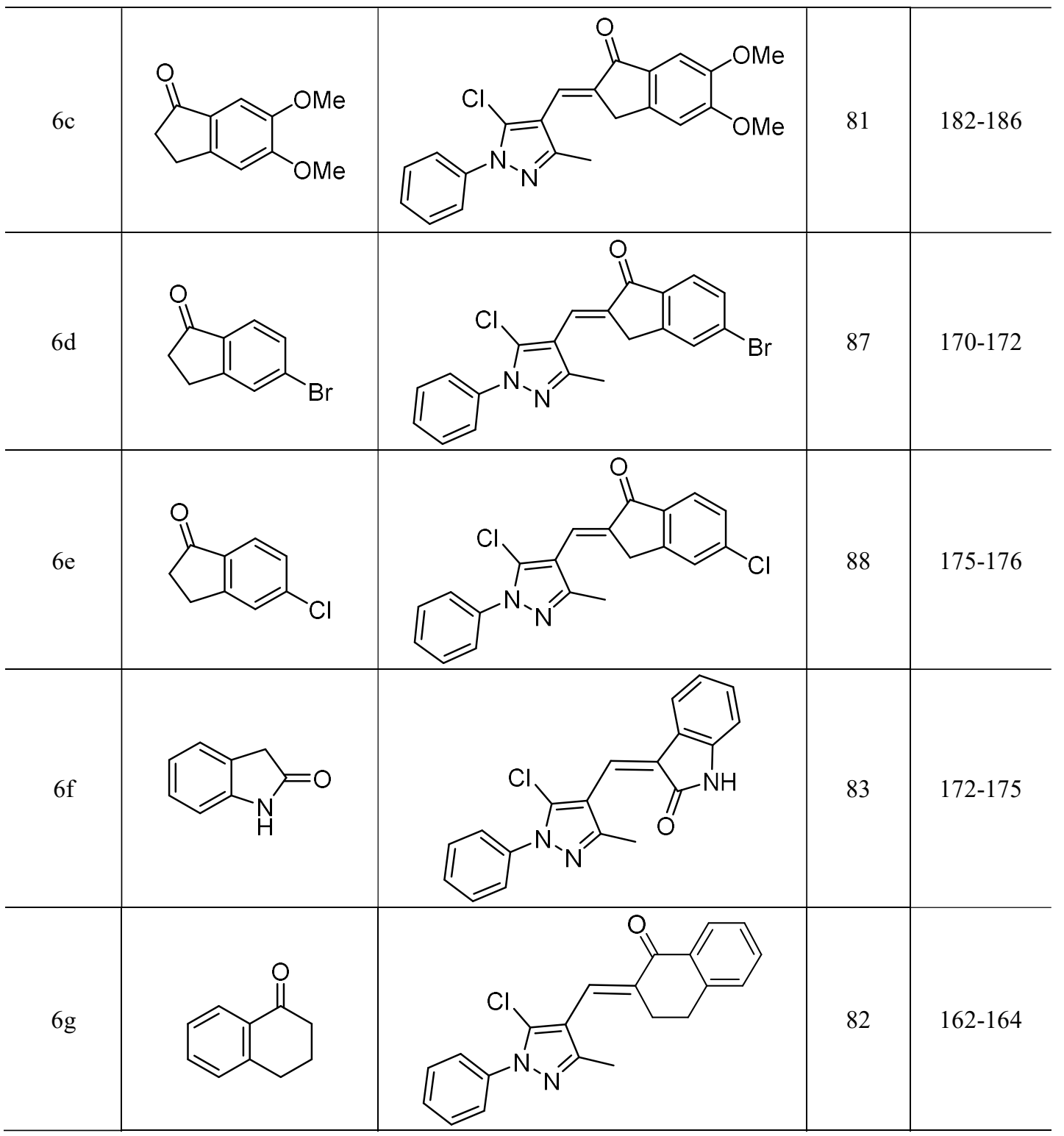<smiles>CCOC(=O)CC(C)=O</smiles>

2<smiles>CC1=NN(c2ccccc2)C(=O)C1</smiles>

3<smiles>COP(=O)(O)OC(=O)OCc1nn(-c2ccccc2)c(Cl)c1C=O</smiles>

4

Scheme-2: Preparation of Precursor Aryl Pyrazole Aldehyde, 4

Biological Evaluation

Anticancer Activity

All the synthesized compounds were screened for their anticancer potential against breast carcinoma (MCF-7) using MTT assay method using paclitaxel as a reference standard drug. The results are summarized in Table-2. The $\mathrm{IC}_{50}$ values revels that compound $\mathbf{6 d}$, 6e and $\mathbf{6 f}$ have shown moderate anticancer activities $\left(\mathrm{IC}_{50} 42.6-53.9 \mu \mathrm{M}\right)$ and all other compounds displayed poor anticancer activities 
RASĀYAN J. Chem.

Vol. 13 | No. 3 |1506-1512| July - September | 2020

against MCF-7. Structure-activity relationship study reveals that the compounds bearing electronwithdrawing groups like chloro, bromo on 1-indanone motif enhances anticancer activity.

\section{Antimicrobial Activity}

All the synthesized compounds also screened for their antimicrobial potential against gram-positive and gram-negative bacteris viz. S. aureus and E. coli respectively using ciprofloxacin as a reference standard The MIC values are presented below in Table-2. The results obtained reveal that most of the synthesized compounds possess significant antimicrobial activities against both the bacterial strains. Among the compounds screened compound $\mathbf{6 a}, \mathbf{6 b}, \mathbf{6 c}, \mathbf{6} \mathbf{d}$ and $\mathbf{6 g}$ exhibited excellent activity against $S$. aureus and compound $\mathbf{6 c}$ and $\mathbf{6 b}$ displayed moderate activity against E. coli. However, remaining compounds showed moderate activity against both $S$. aureus and E. coli.

Table-2: Anticancer and Antimicrobial Screening of the Aryl pyrazole-1-indanone Hybrids

\begin{tabular}{c|c|c|c}
\hline \multirow{2}{*}{ Entry } & $\begin{array}{c}\text { Anticancer Activity } \\
\text { MCF-7 }\end{array}$ & \multicolumn{2}{|c}{$\begin{array}{c}\text { Antimicrobial Activity } \\
\text { MIC }(\mu \mathrm{g} / \mathrm{ml})\end{array}$} \\
\cline { 2 - 4 } & $\mathrm{IC}_{50}(\mu \mathrm{M})$ & S. aureus & E. coli \\
\hline $6 \mathrm{a}$ & 383.7 & 0.4 & 25 \\
\hline $6 \mathrm{~b}$ & 298.5 & 0.7 & 8.50 \\
\hline $6 \mathrm{c}$ & 318.1 & 0.8 & 6.25 \\
\hline $6 \mathrm{~d}$ & 47.0 & 0.8 & 25 \\
\hline $6 \mathrm{e}$ & 42.6 & 1.25 & 21 \\
\hline $6 \mathrm{f}$ & 53.9 & 6.25 & 12.5 \\
\hline $6 \mathrm{~g}$ & 260.2 & 0.9 & 25 \\
\hline Paclitaxel & 0.35 & -- & 2.0 \\
\hline Ciprofloxacin & -- & 2.0 & \\
\hline
\end{tabular}

\section{CONCLUSION}

In conclusion, we have synthesized hybrid molecules by combining aryl pyrazole with various 1indanones under basic conditions. The results of the anticancer study reveal that compounds $\mathbf{6 d}, \mathbf{6 e}$ and $\mathbf{6 f}$ showed moderate anticancer potential against MCF-7 with $\mathrm{IC}_{50}$ values 42.6 to $53.9 \mu \mathrm{M}$. the results of antimicrobial study disclose that compound $6 \mathbf{6}, \mathbf{6 b}, \mathbf{6 c}, \mathbf{6 d}$ and $\mathbf{6 g}$ possess significant inhibition of $S$. aureus (MIC: $0.4-0.9 \mu \mathrm{g} / \mathrm{ml}$ ) and compound $\mathbf{6 c}$ and $\mathbf{6 b}$ possess moderate inhibition of E. coli (MIC: 6.25 $-8.50 \mathrm{mM})$.

\section{REFERENCES}

1. S. Velaparthi, M. Brunsteiner, R. Uddin, B. Wan, S.G. Franzblau, P.A. Petukhov, Journal of Medicinal Chemistry, 51, 1999(2008), DOI:10.1021/jm701372r; (b) N. Ramalakshmi1, S. Deepa, K.S. Srinivas, A. Puratchikody, S. Arunkumar, Rasayan Journal of Chemistry, 2(2), 393(2009); (c) M. Idrees, S. Kola and N. J. Siddiqui, Rasayan Journal of Chemistry, 12(4), 1725(2019), DOI: $10.31788 /$ RJC.2019.1245467

2. I.V. Magedov, M. Manpadi, S. Van slambrouck, W.F.A. Steelant, E. Rozhkova, N.M. Przheval'skii, S. Rogelj, A. Kornienko, Journal of Medicinal Chemistry, 50, 5183(2007), DOI:10.1021/jm070528f.

3. G.C. Rovnyak, R.C. Millonig, J. Schwartz, V. Shu, Journal of Medicinal Chemistry, 25, 1482(1982), DOI: $10.1021 / \mathrm{jm} 00354 \mathrm{a} 018$.

4. G.A. Wachter, R.W. Hartmann, T. Sergejew, G.L. Grun, D. Ledergerber, Journal of Medicinal Chemistry, 39, 834 (1996), DOI:10.1021/jm950377t.

5. F. Colliot, K.A. Kukorowski, D.W. Hawkins, D.A. Roberts, Brighton Crop Protection Conference Pests and Diseases, 1, 29(1992).

6. (a) H.S. Chen, Z.M. Li, Y.F. Han, Journal of Agricultural and Food Chemistry, 48, 5312(2000), DOI:10.1021/jf991065s; (b) C.B. Vicentini, C. Romagnoli, E. Reotti, D. Mares, Journal of Agricultural and Food Chemistry, 55, 10331(2007), DOI:10.1021/jf072077d. 
RASĀYAN J. Chem.

Vol. 13 | No. 3 |1506-1512| July - September | 2020

7. (a) C.B. Vicentini, D. Mares, A. Tartari, M. Manfrini, G. Forlani, Journal of Agricultural and Food Chemistry, 52, 1898(2004), DOI:10.1021/jf035115b; (b) T.W. Waldrep, J.R. Beck, M.P. Lynch, F.L. Wright, Journal of Agricultural and Food Chemistry, 38, 541(1990), DOI:10.1021/jf00092a045; (c) C.B. Vicentini, S. Guccione, L. Giurato, R. Ciaccio, D. Mares, G. Forlani, Journal of Agricultural and Food Chemistry, 53, 3848(2005), DOI:10.1021/jf0500029; (d) R.D. Clark, Journal of Agricultural and Food Chemistry, 44, 3643(1996), DOI:10.1021/jf9601978.

8. (a) H. Yu, I. J. Kim, J. E. Folk, X. Tian, R.B. Rothman, M.H. Baumann, C.M. Dersch, J. L. FlippenAnderson, D. Parrish, A.E. Jacobson, K.C. Rice, Journal of Medicinal Chemistry, 47(10), 2624(2004), DOI:10.1021/jm0305873; (b) M.V. Vita, P. Caramenti, J. Waser, Organic Letters, 17(23), 5832(2015), DOI:10.1021/acs.orglett.5b03002.

9. H.O. Saxsena, U. Faridi, S. Srivastava, J.K. Kumar, M.P. Darokar, et al, Bioorganic and Medicinal Chemistry Letters, 18, 3914 (2008), DOI:10.1016/j.bmcl.2008.06.039.

10. O.A. Fadare, A.A. Akinpelu, H. Ejemubu, C.A. Obafemi, African Journal of Pure and Applied Chemistry, 8(4), 68 (2014), DOI:10.5897/AJPAC2014.0558.

11. S.M.C. Soraires, M. Fabiani, E.F. Castro, L.V. Cavallaro, L.M. Finkielsztein, Bioorganic and Medicinal Chemistry, 25(15), 4055(2017), DOI:10.1016/j.bmc.2017.05.056.

12. N. Siddiqui, M. F. Arshad, S.A. Khan, W. Ahsan, R. Ali, M. S. Alam, S. Ahmed, Medicinal Chemistry Research, 21(6), 726(2011), DOI:10.1007/s00044-011-9584-6.

13. S.K. Mandal, Asian Journal of Pharmaceutical and Clinical Research, 11(5), 278(2018), DOI:10.22159/ajpcr.2018.v11i5.24635.

14. C-Y. Chen, F-Y. Chiu, Y. Lin, W-J. Huang, P-S. Hsieh, F-L. Hsu, International Journal of Molecular Sciences, 16(2), 2497(2015), DOI:10.3390/ijms16022497.

15. Jose C. J. M. D. S. Menezes, RSC Advances, 7, 9357(2017), DOI:10.1039/C6RA28613E.

16. I. Bottcher, A. Schweizer, M. Glatt, H. Werner, Drugs under Experimental and Clinical Research, 13(5), 237(1987).

17. H. Ling, M. Hui, S. Yang, M. Fanchao, L. Xingshu, European Journal of Medicinal Chemistry, 87,429(2014), DOI:10.1016/j.ejmech.2014.09.081.

18. Y. Nakada, S. Ohno, Masafumi Yoshimoto, Yura Yasuo, Agricultural and. Biological Chemistry, 42(7), 1365(1978), DOI:10.1080/00021369.1978.10863166.

19. S. A. Patil, R. Patil, S. A. Patil, European Journal of Medicinal Chemistry, 138, 182(2017), DOI: 10.1016/j. ejmech.2017.06.032.

20. (a) B. P. Bandgar, S. A. Patil, J. V. Totre, B. L. Korbad, R. N. Gacche, B. S. Hote, S. S. Jalde, H. V. Chavan, Bioorganic and Medicinal Chemistry Letters, 2292(2010), DOI:10.1016/j.bmcl.2010.02.001; (b) B. P. Bandgar, L. K. Adsul, S. V. Lonikar, H. V. Chavan, S. N. Shringare, S. A: Patil, S. S. Jalde, B. A. Koti, N. A. Dhole, R. N. Gacche, A. Shirfule, Journal of Enzyme Inhibition and Medicinal Chemistry, 28, 593(2013), DOI:10.3109/14756366.2012.663365; (c) P. S. Bhale, H. V. Chavan, S. B. Dongare, S. N. Shringare, Y. B. Mule, S. S. Nagane, B. P. Bandgar, Bioorganic and Medicinal Chemistry Letters, 27, 1502(2017), DOI:10.1016/j.bmcl.2017.02.052; (d) H. V. Chavan, L. K. Adsul, A. S. Kotmale, V. D. Dhakane, V. N. Thakare, B. P. Bandgar, Journal of Enzyme Inhibition and Medicinal Chemistry, 30, 22(2015), DOI: $10.3109 / 14756366.2013 .873037$.

21. (a) J. M. Andrews, Journal of Antimicrobial Chemotherapy, 48(1), 5(2001), DOI:10.1093/jac/48.suppl_1.5; (b) K.D. Tripathi, 2013, Essentials of Medical Pharmacology (7th ed.). New Delhi, India: Jaypee Brothers Medical Publishers, pp. 696.

[RJC-5716/2020] 